\title{
Definitive Laparoscopic Treatment of Huge Tubo-ovarian Abscess: Report of a Difficult Case
}

\author{
Dev Tubo-ovaryan Apsede Başarılı Laparoskopik Tedavi: Zor Bir Olgu Sunumu
}

Yavuz ŞIMŞEK

\section{$\underline{0 ̈ Z}$}

Tubo-ovaryan apse, pelvik inflamatuar hastalığın en ileri aşamasıdır ve pelvik enfeksiyonu olan kadınlarda ana ölüm nedenidir. Bu yazıda, kliniğimize kronik karın ağrısı ve $38{ }^{\circ} \mathrm{C}$ üzerinde ateş yakınması ile başvuran, ultrasonografide sağ adneksiyal bölgede $15 \times 18$ $\mathrm{cm}$ boyutlarında semisolid kitlesi bulunan bir hastayı sunduk. Hasta tubo-ovaryan apse tanısıyla yatırıldı ve geniş spektrumlu ampirik antibiyotik tedavisi başland. Buna karşın ateşin düşmemesi ve ağrının dinmemesi üzerine hasta laparoskopik cerrahiye alındı. Laparoskopide sağda tüp ve overi içine alan, üzeri ince barsak ve appendiks ile kaplı, aynı zamanda sigmoid kolonla iltisaklı apse görüldü. İntestinal segmentler nazikçe diseke edildi ve apse usulüne uygun olarak eksize edildi. Hasta postoperatif 5. günde sağlikla taburcu edildi.

Anahtar Kelimeler: Laparoskopi; pelvik inflamatuar hastalı; tubo-ovaryan apse

\section{ABSTRACT}

Tubo-ovarian abscesses are the end stage of pelvic inflammatory disease, and the main cause of mortality in women with pelvic infection. Here, we report a woman at 22 years of age, presenting with severe abdominal pain and fever $>38{ }^{\circ} \mathrm{Celcius}$ and sonographically diagnosed with a semisolid adnexal mass with $15 \times 18 \mathrm{~cm}$ in diameters on the right side. The woman was hospitalized with a diagnosis of tubo-ovarian abscess, and empiric broad-spectrum antibiotic therapy was started. However, pain and fever were not subsided. The patient underwent a laparoscopic surgery and a huge tubo-ovarian abscess covered by small intestines and appendix and adhered to the sigmoid colon was seen. Intestinal segments were gently dissected, and abscess, including the right ovary and the right tube, was excised appropriately without any complication. The patient was discharged on the 5th postopera tive day with complete healing.

Keywords: Laparoscopy; pelvic inflammatory disease; tubo-ovarian abscess

Received: 26.04.2020; Accepted: 03.07.2020

Corresponding Author: Yavuz Şimşek. Kırşehir Ahi Evran University, Medical Faculty, Department of Obstetrics and Gynecology. Kirşehir E-mail: dryavuzsimsek@ gmail.com

How to cite: Şimşek Y. Definitive laparoscopic treatment of huge tubo-ovarian abscess: Report of a difficult case. Ahi Evran Med J. 2020;4(2):56-59. 


\section{INTRODUCTION}

As a severe form of pelvic inflammatory disease (PID), tubo-ovarian abscess (TOA) is the collection of pus in the upper genital organs, including ovary, tube, and adjacent pelvic structures. ${ }^{1}$ TOA needs hospitalization and urgent intervention due to the potential risk of rupture of the abscess and secondary peritonitis, and sepsis, both conditions are life-threatening. ${ }^{1}$ It generally affects women in their reproductive ages. Therefore, timely and appropriate management is vital for these cases to save future fertility, and the life of the patient. Although the broad-spectrum antibiotherapy is the main treatment of women with TOA, resistant cases to antibiotherapy or with suspicion of rupture need emergency surgery. ${ }^{2}$ Surgical management of TOA is generally a complex procedure that may require dissection of intestines, omentum, and ureter, which all may have adhered to the abscess wall in these cases. Laparotomy rather than laparoscopy has been the choice of treatment in cases of TOA in daily practice since TOA-related adhesions between the abscess wall and abdominal surface, intestines and adjascent pelvic structures can cause higher risk of complications during laparoscopy. ${ }^{1,2}$ Although excision of abscess along with all infected tissues is desirable, drainage and irrigation of abscess cavity are mostly performed surgical interventions rather than total excision of infected tissues, which requires broad surgical expertise. ${ }^{3}$ Recently, a successful laparoscopic treatment of these cases was also reported. ${ }^{3,4}$ Here, we report a case of a young woman who had a huge TOA in the right adnexa and successfully treated with complete laparoscopic excision.

\section{CASE REPORT}

A-22-year-old sexually active woman, G0P0, with a normal medical history, was presented to our outpatient clinic with severe abdominal pain at the lower abdomen, and dysuria for one week of duration and episode of shivers and fever during this time. She described a chronic lower abdominal pain for a month which gradually increased and became unbearable in the last days before admission. On admission, the patient was ill, and vital signs were as follows: body temperature was $38.8{ }^{\circ} \mathrm{C}$, the heartbeat was $103 \mathrm{ppm}$, and her blood pressure was $110 / 60 \mathrm{mmHg}$. The patient's physical and vaginal examination showed severe abdominal tenderness to deep palpation of lower quadrants, malodorous and yellowish vaginal discharge, and ectocervicitis. Both transvaginal and transabdominal sonography were commenced, and minimal pelvic fluid in Douglas' pouch and a right adnexal mass with diameters of $15 \times 18 \mathrm{~cm}$ was diagnosed. The left ovary and uterus were seen as normal. The results of laboratory tests including complete blood count, c-reactive protein (CRP), Cancer antigen 125 (Ca-125), and urinalysis were as follows: White blood count (WBC): 17,800 $\mu \mathrm{L}$ (81\% neutrophils); Hemoglobin (Hb): 11,7 g/dL; platelets (PLT): 210,000 $\mu \mathrm{L}$; CRP: 78 mg/L; Ca-125: $59 \mathrm{U} / \mathrm{ml}$ (reference range < $35 \mathrm{U} / \mathrm{mL})$ and urine analysis with microscopy: WBC (+), nitrite (-), and bacteria (-). She was hospitalized with a presumptive diagnosis of pelvic infection with TOA. Intravenous (IV) hydration and 2 gr IV ceftriaxone (cefaday ${ }^{\circledR}$ 1gr, Biofarma, Istanbul, Turkey) $1200 \mathrm{mg}$ IV clindamycin (Klindan ${ }^{\circledR} 600 \mathrm{mg}$, Bilim İlaç, Istanbul, Turkey) and Gentamicin IV $3 \mathrm{mg} / \mathrm{kg}$ (daily dose of 160 mg) (Gentrex ${ }^{\circledR} 80 \mathrm{mg}$, Bilim İlaç, Istanbul, Turkey) were administered. Daily intramuscular injection of diclofenac sodium (Dikloron ${ }^{\circledR}$, Deva Holding, Istanbul, Turkey) was also added. On the second day of these medical treatments, the patient's fever was not subsided, abdominal tenderness was worsened, and repeated CRP levels were increased to $120 \mathrm{mg} / \mathrm{L}$. A laparoscopic surgical intervention was decided. Veress needle was placed $3 \mathrm{~cm}$ above the umbilicus to avoid the inadvertent rupture of the abscess, and pneumoperitoneum was achieved using carbon dioxide (12 $\mathrm{mm} \mathrm{Hg}$ ), after which a 10-mm port was placed for the camera. Two further 5$\mathrm{mm}$ ports were introduced to the left and right side of the abdomen, and an additional 5-mm supraumbilical trocar was inserted. Laparoscopic observation revealed a huge TOA, including the right ovary and tube, covered with small intestines and appendix (Figure 1a). Uterus and left 
adnexa, and upper abdominal organs were normal. Loops of small intestine adhered to the abscess wall and appendix were freed by hydrodissection combined with gently blunt dissection. The abscess base has been adhered to the sigmoid colon and this adherence was opened by the same methods. Pelvic peritoneum was opened on the right side behind the round ligament by laparoscopic scissor, and right ureter along its course from the pelvic brim to the base of the abscess was clearly identified by blunt dissection. The abscess, including the right ovary and the right tube, was excised completely using an energy device (LigaSure ${ }^{\mathrm{TM}} 5 \mathrm{~mm}$ ) (Figure 1b). The right-sided 5-mm trocar was removed, and the entrance was widened to $10 \mathrm{~mm}$. An endo bag was inserted from this point, and the endobag removed TOA from the right side. The abdomen and pelvis were copiously irrigated, and a closed suction drain was placed to the pouch of Douglas. Intraabdominal $\mathrm{CO}_{2}$ was removed from the 5-mm left and supraumbilical trocars. Port sites were closed including fascia and skin by Vicryl sutures, and operation was finished. An intensive care unit follow-up was not needed, and the patient was transferred to the ward. The toxic picture of the patient and abnormal laboratory values were dramatically improved in the following days. IV antibiotherapy was continued, and the patient was discharged with complete healing on the 5th postoperative day. Informed consent was obtained for this case report from the patient.

\section{DISCUSSION}

Broad-spectrum antibiotic therapy has been accepted as the first-line treatment of TOA with a reported success rate of $34-88 \% .^{3,4}$ In cases of failed antibiotic therapy, an urgent surgical treatment is required. Laparoscopic surgery has clear advantages over laparotomy in terms of fast postoperative recovery, less need of painkiller medications, and less duration of hospital stay; however, especially in difficult cases such as TOA, the risk of inefficient surgery and iatrogenic organ injury are more common in laparoscopy mainly depending on the surgeon's experience and expertise on endoscopic surgery. Therefore, a clear conclusion on the route of surgery in cases with TOA is still debatable. ${ }^{3-5}$
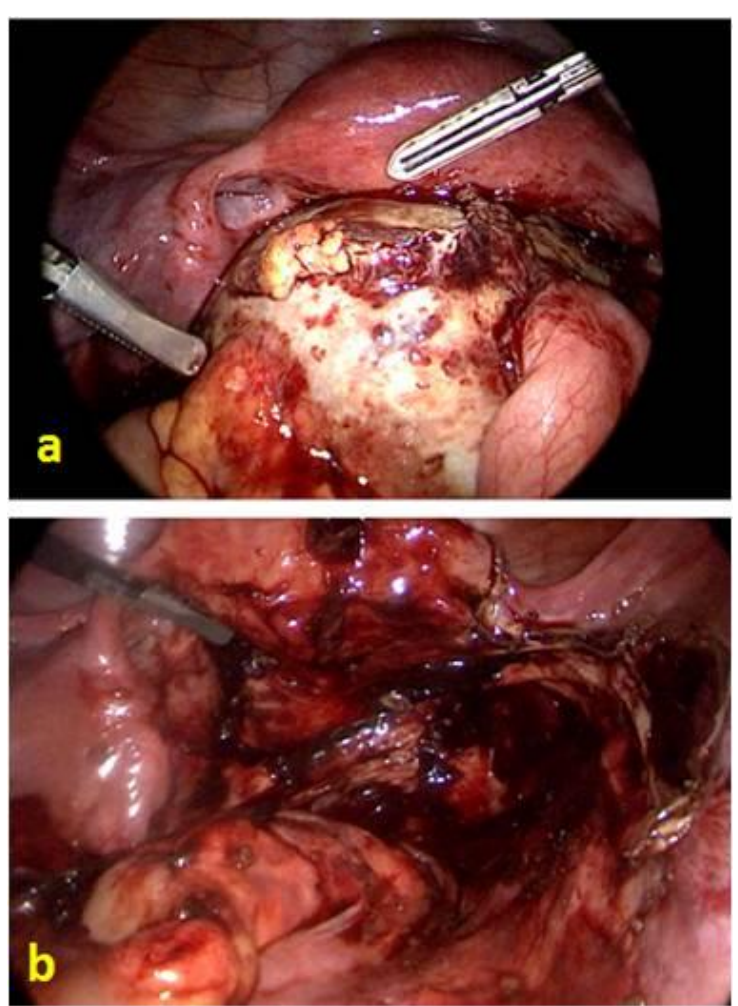

Figure 1. Laparoscopic view of the bulky tubo-ovarian abscess on the right adnexa covered with intestinal loops, sigmoid colon, and appendix (a) Laparoscopic view of the pelvis after resection of TOA with preserving left tube, left ovary and uterus (b)

In their case series, Buchweitz et al. reported successful laparoscopic management of TOA cases with no operative complications or serious systemic sequelae. ${ }^{3}$ Chu et al. ${ }^{4}$ also reported a response rate of $90-100 \%$ of laparoscopic treatment without any severe complications in cases with TOA. In the present case, we performed a laparoscopic radical excision of the abscess and infected tissues; however, in both case series mentioned above, only laparoscopic drainage of abscess rather than radical excision was commenced. A recently published study focusing on the clinical predictors for successful surgical treatment in cases of TOA also recommends laparoscopic treatment, if the patient is suitable and the surgeon is skilled for advanced laparoscopy. ${ }^{5}$

In conclusion, laparoscopy, with its patient-friendly properties, can be a treatment choice in cases with TOA for drainage of abscess cavity, and the definitive treatment including resection of infected tissues. 


\section{CONFLICT OF INTEREST}

The authors declare no conflict of interest.

\section{REFERENCES}

1. Curry A, Williams T, Penny ML. Pelvic inflammatory disease: diagnosis, management, and prevention. Am Fam Physician. 2019;100(6):357-364.

2. Rosen M, Breitkopf D, Waud K. Tubo-ovarian abscess management options for women who desire fertility. Obstet Gynecol Surv. 2009;64(10):681-689.

3. Buchweitz O, Malik E, Kressin P, Meyhoefer-Malik A, Diedrich K. Laparoscopic management of tubo-ovarian abscesses: retrospective analysis of 60 cases. Surg Endosc. 2000;14(10):948-950.

4. Chu L, Ma H, Liang J, et al. Effectiveness and adverse events of early laparoscopic therapy versus conservative treatment for tubo-ovarian or pelvic abscess: A singlecenter retrospective cohort study. Gynecol Obstet Invest. 2019;84(4):334-342.

5. Fouks Y, Cohen A, Shapira U, et al. Surgical intervention in patients with tubo-ovarian abscess: clinical predictors and a simple risk score. J Minim Invasive Gynecol. 2019; 26(3):535-543 